\title{
Subscapular Skinfold Thickness
}

National Cancer Institute

\section{Source}

National Cancer Institute. Subscapular Skinfold Thickness. NCI Thesaurus. Code $C 98785$.

A measurement of the thickness of a pinch of skin situated below or on the underside of the scapula. 